\title{
Business Model Based on Coffee Husk Bioconversion by Black Soldier Fly (Hermetia Illucens) and Agroforestry System in Bandung Regency, West Java
}

\author{
*Pathmi Noerhatini ${ }^{1}$, Amanna D. Al Hakim ${ }^{2}$, Yeyet Setiawati ${ }^{3}$, Siti K. Azhari ${ }^{1}$, \\ Dicky R. Munaf ${ }^{1}$ and Raka M. Azka ${ }^{4}$ \\ ${ }^{1}$ Humanity Research Group, Faculty of Art and Design, ITB, Bandung, Indonesia \\ ${ }^{2}$ Management Study Program, Faculty of Business and Humanities, Nusa Putra University, Indonesia \\ ${ }^{3}$ School of Life Science and Technology, ITB, Bandung, Indonesia \\ ${ }^{4}$ Students of Faculty of Mining and Petroleum Engineering, ITB, Bandung, Indonesia \\ *Corresponding author. Email: pathmi@fsrd.itb.ac.id
}

\begin{abstract}
Planting coffee under forest stands in an agroforestry system by members of the Forest-Village Non-government Organization (FVNGO) is one of the techniques for forest maintenance in Bandung Regency, West Java. Because they are unfamiliar with the husk's bioconversion, coffee husk waste from the early processing of coffee cherries is frequently thrown away or not used economically. The Covid-19 pandemic affected coffee fruit prices too. As a result, we empower coffee farmers by using Black Soldier Fly (Hermetia illucens/BSF) to the bioconvert coffee husk. Large amounts of coffee husk in one community of coffee farmers will encourage the creation of a business because the results of bioconversion by BSF produce solid and liquid organic fertilizers, magot for chicken feed, and chicken manure can be used for fertilizing coffee plantations and BSF feed. The research aims to develop a business model based on this bioconvert. The research was carried out in three stages: the agroforestry system's socialization based on feeding coffee waste by BSF, product development, and commercial activities. This research showed that BSF's bioconversion technology creates a business of coffee and bioconversion products. Based on BMC's analysis, the business models that are following the bioconversion are direct selling and digital platforms.
\end{abstract}

Keywords: Business Model, Coffee Husk Waste, Bioconversion of Coffee Waste by BSF, Agroforestry System.

\section{INTRODUCTION}

Indonesia's coffee consumption during the period 2016-2021 has grown at an average of $8.22 \%$ /year. The consumption of coffee is predicted reaching 370 thousand tons in 2021. This number increased by 425 thousand tons [1]. This coffee surplus is a challenge for the government and other stakeholders, so efforts are needed to increase domestic consumption, which is the best solution to realize a national coffee sector that is resilient and sustainable in the long term. Another problem is that about $94.5 \%$ of coffee production in Indonesia is supplied from people's plantation coffee entrepreneurs (farmers with a land area of fewer than two hectares) with diverse coffee quality. Meanwhile, $81.87 \%$ of national coffee production is Robusta, derived from coffee plantations in South Sumatra, Lampung, Bengkulu, East Java, and Central Java. While West Java coffee production amounted to $21,198.37$ tons from farmer's plantations, 28.9 tons from large state plantations, and 48.47 tons from large private plantations [2].

Coffee cultivation in West Java is partly by members of the Forest-Village Nongovernment Organization (FFNGO) under the forestry tree stand in the agroforestry system as one of the strategies for forest maintenance in Bandung Regency. 
The economic and ecological benefits of agroforestry systems are increasing organic matter. The phosphorus levels in the soil, tree plants arranged as fences to reduce erosion, speed, and wind direction, timber producers, feed sources, and shelter livestock from sunlight and strong winds. This system can absorb 0.97 million litters more water than the monoculture agricultural system for every hectare of land every hour of rain, which is helpful for erosion and flood prevention [3].

Coffee processing, either small-scale or industrial scale, will certainly produce by-products of coffee processing, one of which is coffee husk waste. The processing will produce $\pm 65 \%$ coffee beans and \pm $35 \%$ coffee husk. The content in the coffee skin itself has the following nutritional content CP 9.94\%, SK $18.17 \%$, Fat $1.97 \%$, ash $11.28 \%$, Ca $0.68 \%$, P $0.20 \%$, GE 3306 Kcal and TDN 50.6\% [4].

The problem at FVNGO is the waste of the husk of the coffee fruit from the initial processing of coffee fruit, which is often only discarded or economically untapped and does not know the bioconversion of the waste. Another problem is that partner members still use synthetic NPK fertilizer so that soil fertility conditions continue to decline. Also, members are still bringing chicken manure from other districts to increase production costs and reduce farmers' resistance to production inputs derived from internal areas; we have proposed a community service program 2021 with the aim of mentoring FVNGO members) through the application of bioconversion of coffee husk waste and vegetable waste by BSF (black soldier fly/ Hilmetia illucens), which results in solid and liquid organic fertilizer for the plantation of coffee, vegetables, and grass. Furthermore, maggot from BSF for chicken feed, the grass is used as cow feed, and vegetable waste for chicken feed, where chicken manure can be used as BSF feed.

Suppose we calculate the amount of coffee husk waste generated from one community of coffee farmers. In that case, it will create opportunities for business from the bioconversion of coffee fruit skin waste by BSF. The bioconversion of coffee husk waste results in solid organic fertilizer to increase soil fertility, maggots for chicken feed, and village chicken manure for BSF feed and coffee plantations [5]. Therefore, we will create a business model of the bioconversion process in the agroforestry system.

\section{LITERATURE REVIEW}

\subsection{Coffee Husk Waste}

Another challenge for all stakeholders is that Indonesian coffee is also known in the global market because of its distinctive aroma; Indonesian coffee currently competes with Brazilian coffee. The Minister of Agriculture also targets that coffee exports triple in the next five years. He encouraged upstream producers and exporters to innovate products to be popular with the market [1].

The development of coffee production and processing will certainly produce by-products of coffee processing: coffee husk waste. Coffee husk has the following nutritional content CP 9.94\%, SK $18.17 \%$, Fat $1.97 \%$, Ash $11.28 \%$, Ca $0.68 \%$, P 0.20\%, GE $3306 \mathrm{Kcal}$ and TDN 50.6\% [4]. According to LIPI (Indonesian Institute of Science), there was $56.8 \%$ of the weight of coffee beans and $43.2 \%$ of the husk and flesh of coffee fruit in cherry coffee. So, when data on Indonesian coffee production in 2018 reached 674,636 tons, then the ingredients are not utilized in the form of skin and meat of coffee fruit reached 276,179 tons [2]. This number shows that the husk and flesh of coffee fruit becomes a potential by-product and worth developing, for example, using appropriate technology for advanced treatment of this coffee cherry husk so that the coffee husk waste can be utilized economically.

Members of coffee farmers who are members of the FVNGO Tenjolaya (Bandung regency) have not optimally processed coffee husk waste but instead burned or disposed of it, and a small portion was used as fertilizer and animal feed. They do not know how to treat coffee husk waste from the initial processing of coffee cherries. Another problem is that some FVNGO Tenjolaya still uses synthetic NPK fertilizers so that soil fertility conditions continue to decline. Members also bring in chicken manure from another regency, increasing production costs and reducing farmers' resistance to production inputs from internal sources.

\subsection{Bioconversion coffee husk waste by BSF}

The technology applied to this farmer group is the bioconversion of coffee fruit husk waste by BSF. The bioconversion process by BSF begins with the preparation of BSF larvae feed in the form of fermented coffee husk waste, vegetable waste, chicken manure in a ratio of $1: 1: 1$, then fermented for $2-3$ weeks. Furthermore, the process of feeding by BSF larvae, which then larvae become prepupae, pupae, and adult insects. The next BSF life cycle is reproduction into eggs, and eggs hatch into larvae [6]. The bioconversion of organic waste results can be in the form of solid and liquid organic fertilizers [7]. At the same time, 21-day-old BSF larvae have a protein content of $40.18 \%$ dry matter, and crude fat of $28.92 \%$ dry matter using organic waste [8], [9] can be used as chicken feed. 


\subsection{Create a business model based on the processing of coffee husk waste}

In Indonesia, the value chain of coffee changed significantly, which provide opportunities and challenges for Government to develop economic stability [10]. The sustainable economic sector encourages several studies to utilize coffee waste as a product that is more useful, has economic value, and creates zero waste in the environment. Usman and Nanda's research [11] proposed a green business opportunity model of the recycling process of coffee grounds produced by coffee shops to become fertilizer, which is implemented in the urban farming community in Surabaya.

Based on research on five Agri-food-Tech ebusiness models, which were analyzed based on the Business Model Canvas to identify interacting components that create and deliver value, suggest future innovative business models [12]. The business model is based on digital technology as a sustainable and scalable resource in the Agri-food sector and is expected to encourage interaction between costumers and producers.

\section{RESEARCH METHODS}

The research is in Pasirjambu District, Bandung Regency, West Java. The area of Pasirjambu District is $239.49 \mathrm{~km} 2$, most of which are between the hills and mountains surrounding the Pasirjambu District, and this area is mainly located at Patuha mountain with an altitude of 900 to 2,334 $\mathrm{m}$ above sea level, with a slope of $8-15 \%$. To above $45 \%$, tropical climate influenced by monsoon climate with average rainfall between 1,500 to $4,000 \mathrm{~mm}$ per year, air temperature ranging from $10 \mathrm{o}$ to $24 \mathrm{o} \mathrm{C}$ with humidity between $78 \%$ in the rainy season and $70 \%$ in the dry season.

The research method used a qualitative approach. Data collection technique through Focus Group Discussion (FGD) and in-depth interviews. The study was conducted at the FVNGO Tenjolaya, which consisted of 313 members divided into six groups. The FGDs were conducted twice, each with six members representing the six groups, so the total number of respondents who participated in the FGD was 12 people.
In-depth interviews with research subjects were conducted semi-structured using interview guidelines. The research subjects in in-depth interviews are coffee farmers involved in the coffee business who are deliberately selected and have at least been growing coffee for at least five years.

The data collected using FGDs and in-depth interviews were then recorded, typed, and edited. Data analysis was carried out using an interactive model following the opinion of Miles and Huberman [13]. In this model, data reduction, data presentation, and conclusion drawing are carried out, all three of which are a cycle to strengthen conclusion drawing. This means that the data collected and analyzed are qualitative as a qualitative method. Data in the form of words is not intended to draw generalizations but emphasizes more on meaning, so this research is classified as descriptive research.

\section{RESULTS AND DISCUSSION}

\subsection{Typology of Coffee Farmers}

Farmers' household livelihood strategies are divided into survival, consolidation, and accumulation strategies [14]. Survival farmer focus on how to survive at minimum level of life, consolidation farmer focus to fulfill their daily needs, and accumulation farmer focus to fulfill their needs of life. The limitations of the members of this organization were lack of information from the government (18\%), lack of access to information (18\%), diversity of coffee processing/quality of processed coffee $(27 \%)$, lack of information/market access (12\%), lack of GAP SOPs for coffee cultivation (3\%), lack of capital and land for coffee processing (18\%) and no coffee processing equipment $(3 \%)$. Based on these limitations, we examined their needs, namely guidelines in the form of SOP GAP (Standard Operational Procedure of Good Agriculture Practices) were 22\%, guidelines in the form of SOP GHP (Good Handling/Postharvest Practices) were $30 \%$, postharvest equipment was $4 \%$, and market access for coffee was $44 \%$. 


\subsection{Mapping for Positioning Products}

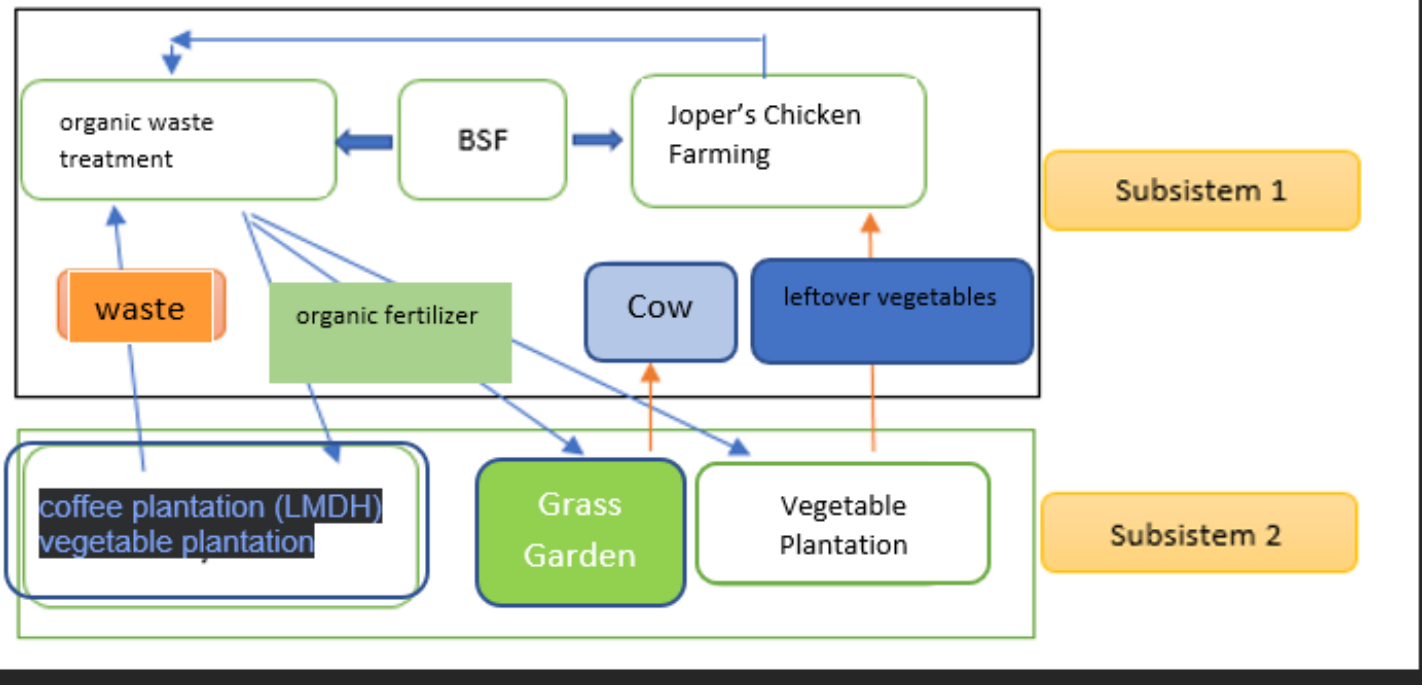

Figure 1: Product Positioning based on Bioconversion Coffee Waste by BSF and Agroforestry System

The Agroforestry system consists of forestry trees and two subsystems. Subsystem 1 consists of the cultivation of chickens and BSF cultivation, which produces maggot feed for livestock chickens, and chicken manure is used as BSF feed. BSF cultivation in the form of larvae and BSF prepupa act as a source of protein feed for chicken feed. BSF with 21-day-old larvae has a protein content of $40.18 \%$ dry matter and crude fat of $28.92 \%$ dry matter using organic waste's bioconversion [8], [9]. Chicken manure can be used for BSF feed. The output obtained from subsystem 1 for subsystem two is organic fertilizer produced by BSF bioconversion. The fertilizer is used in subsystem
2 to cultivate coffee, vegetables, and forage grass (cow feed). Subsystem 2 consists of cultivating coffee, vegetables, and grass, where the husk waste of coffee, fruit, and vegetables will be BSF feed. In contrast, vegetable waste can be used as chicken and grass as cow feed.

\subsection{Creating a Business Model}

Based on the identification of the main needs for digital-based businesses, it is necessary to create the BMC Analysis of the AgriFood-Tech Model [12] with the following explanation.

Table 1. Business Model Canvas based on Bioconversion by BSF

\begin{tabular}{|c|l|}
\hline Value proposition & $\begin{array}{l}\text { Produce and process high-quality products from bioconversion by BSF through } \\
\text { empowering smallholder coffee farmers }\end{array}$ \\
\hline Key partners & Coffee Farmer group, university, government (agriculture department), BUMDes \\
\hline Key activities & $\begin{array}{l}\text {-Training of bioconversion coffee waste by BSF and crop management } \\
\text {-Packaging process: bioconversion products } \\
\text {-Marketing and selling to other farmer groups and company }\end{array}$ \\
\hline Key resources & $\begin{array}{l}\text {-Shelter in coffee land (agroforestry system) } \\
\text {-Equipment for bioconversion coffee waste by BSF } \\
\text {-Market access } \\
\text { Relationships }\end{array}$ \\
\hline Customer & $\begin{array}{l}\text { - Competitive prices } \\
\text { - } \text { - Farm tour }\end{array}$ \\
\hline
\end{tabular}




\begin{tabular}{|c|l|}
\hline Channels & $\begin{array}{l}\text {-Instagram and whatsap groups } \\
\text {-Direct selling to coffee farmers } \\
\text {-Online selling through website and marketplace: coffee and bioconversion products }\end{array}$ \\
\hline Customer & Mass: especially organic coffee consumers, coffee farmer groups \\
\hline Cost structure & $\begin{array}{l}\text {-Training farmers for sustainable coffee and bioconversion products } \\
\text {-Marketing } \\
\text {-Shipping } \\
\text {-Postharvest processing } \\
\text {-Laboratorium test }\end{array}$ \\
\hline Revenue stream & $\begin{array}{l}\text {-Sell of fresh cherry and grean bean's coffee } \\
\text {-Sell of bioconversion products } \\
\text {-Sell of farm tour }\end{array}$ \\
\hline
\end{tabular}

Based on the BMC above, it is necessary to choose the digital [12] Figure 2 technology and direct selling. The digital platform contains several features, namely dashboard, group data feature, coffee condition feature, and info feature

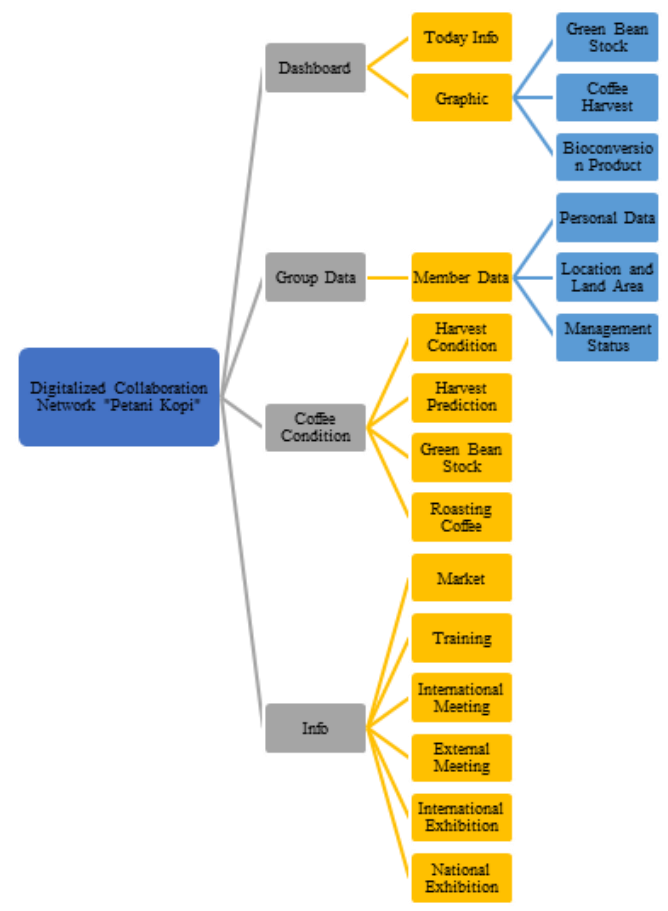

Figure 2. Digital platform for coffee and bioconversion product marketing

The following features are coffee conditions: harvest conditions (existing harvest potential), harvest predictions, green bean stock in members and groups, and roasting coffee stock. The dashboard feature consists of today's info and graphics based on the scheme. The group data feature consists of information on member data, namely personal data, location, land area, and management status. The last feature is the info feature consisting of market info, training, international meetings, regional meetings, international exhibitions, and regional exhibitions. 
Members and managers have a unique password to $\log$ in to the ICT system. Managers have access to the market, while members will receive limited information so that there is no internal competition. The digital community will be formed if community members always provide and search for the latest information on the digital platform, communicate periodically and maintain mutual cohesiveness and transparency. This platform will inform the contact number that can be contacted, which is entrusted to the administrator.

\section{CONCLUSION}

Typology of coffee farmers as members of FVNGO Tenjolaya is coffee farmers who also as vegetables farmers, so there are two sides of this, namely FVNGO members get additional income from coffee products, while the other side is that they also focus on vegetable crops. They have the potential to form communities based on economic and social interests. But they have weaknesses in market access, technology access, and mentoring access.

Based on social empowerment to coffee farmers about the bioconversion technology of coffee husk waste by BSF gave rise to a coffee business and products from the bioconversion. Based on BMC's analysis, the business models that are in accordance with the bioconversion are direct selling and digital platforms (websites).

\section{ACKNOWLEDGMENTS}

We would like to thank LPPM ITB, which provides research funding. Thanks, were also conveyed to the members of the Forest-Village Nongovernment Organization (FFNGO) Tenjolaya, Pasirjambu subdistrict, Bandung district. To CV Lyco farm as a research partner, we also thank you.

\section{REFERENCES}

[1] D. R. Triyanti, “Outlook Kopi 2016,” Jakarta, 2016. [Online]. Available: http://epublikasi.setjen.pertanian.go.id/arsipoutlook/75-outlook-perkebunan/420-outlookkopi-2016.

[2] Badan Pusat Statistik, "Badan Pusat Statistik: Statistik Kopi Indonesia 2019,” Badan Pusat Statistik Indonesia, Jakarta. [Online]. Available:

https://www.bps.go.id/publication/2020/12/0 2/de27ead7c1c7e29fd0aa950d/statistik-kopiindonesia-2019.html.

[3] A. Ma'ruf, “Agrosilvopastura Sebagai Sistem Pertanian Terencana Menuju Pertanian
Berkelanjutan," Bernas, vol. 13, no. 1, pp. 8190, 2017, doi: 10.31227/osf.io/295bk.

[4] N. L. G. Budiarti, "Pengaruh Aras Kulit Kopi Terfermentasi Dalam Ransum Terhadap Pertumbuhan Kelinci Lokal Jantan ( Lepus negricollis )," pp. 1-164, 2014.

[5] A. D. A. H. and R. M. A. Noerhatini, P., Y. Setiawati, "Sistem Agrosilvopastura Berbasis Biokonversi Limbah Kulit Buah Kopi dan Sayuran oleh Black Soldier Fly (Hermetia Illucens) sebagai Upaya Pencegahan Longsor," Pameran Poster di Lemb. Penelit. dan, 2021.

[6] B. Dortmans, S. Diener, B. Verstappen, and C. Zurbrügg, Pengolahan Sampah Organik Dengan Black Soldier Fly (BSF), vol. 1. Switzerland: Eawag - Swiss Federal Institute of Aquatic Science and Technology D epartment of Sanitation, Water and Solid Waste for Development (Sandec), 2017.

[7] Mujahid, A. A. Amin, Hariyadi, and M. R. Fahmi, "Biokonversi Tandan Kosong Kelapa Sawit Menggunakan Hermetia illucens dan Trichoderma sp. Menjadi Bahan Pakan Unggas dan Ikan.," J. Ilmu Produksi dan Teknol. Has. Peternak., pp. 5-10, 2018, [Online]. Available: http://repository.ipb.ac.id/handle/123456789/ 91570.

[8] S. Munira, L. O. Nafiu, and A. M. Tasse, "Performans Ayam Kampung Super Pada Pakan Yang Disubttusi Dedak Padi Fermentasi Dengan Fermentor Berbeda," 1991.

[9] M. A. Wiranata, J. I. Sanyoto, and H. Subagja, "Analisis Profitabilitas Usaha Peternakan Ayam Kampung Super di Kabupaten Jember," J. Ilmu Peternak. Terap., vol. 1, no. 1, 2017, doi: 10.25047/jipt.v1i1.534.

[10] J. Neilson, "The Value Chain for Indonesian Coffee in A Green Economy," J. Tanam. Ind. dan Penyegar, vol. 4, no. 3, 2013, doi: 10.21082/jtidp.v4n3.2013.p183-198.

[11] P. V. Nanda and I. Usman, "Green business opportunity of coffee ground waste through reverse logistics," J. Glob. Bus. Adv., vol. 10, no. $6, \quad 2017, \quad$ doi: 10.1504/jgba.2017.10013145.

[12] M. Vlachopoulou, C. Ziakis, K. Vergidis, and M. Madas, "Analyzing agrifood-tech ebusiness models," Sustain., vol. 13, no. 10, 2021, doi: 10.3390/su13105516. 
[13] B. M. dan M. H. Miles, "Analisis Data Kualitatif Buku Sumber Tentang Metodemetode Baru," UIP, 1992.

[14] B. White, "Economic Diversification and Agrarian Change in Java: 1900-1990," In The Shadow of Agriculture: Non-Farm Activities in The Javanese Economy: Past and Present. 1991. 